\title{
Petrography, Sedimentary Environments and Sequence Stratigraphy of Asmari Formation in Central Fars, Zagros, SW (Iran)
}

\author{
Reza Mirzaee Mahmoodabadi ${ }^{1,2}$ \\ ${ }^{1}$ Department of Geology, Estahban Branch, Islamic Azad University, Estahban, Iran \\ ${ }^{2}$ Young Researchers and Elite Club, Estahban Branch, Islamic Azad University, Estahban, Iran \\ Email: $\underline{r \text { mirzaeem@iauest.ac.ir, rmirzaeem1@Hotmail.com }}$
}

Received 25 October 2014; revised 20 November 2014; accepted 18 December 2014

Copyright (C) 2014 by author and Scientific Research Publishing Inc.

This work is licensed under the Creative Commons Attribution International License (CC BY). http://creativecommons.org/licenses/by/4.0/

(c) (i) Open Access

\section{Abstract}

To study petrography, microfacies, sedimentary environments and sequence stratigraphy of Asmari formation in central Fars, 4 stratigraphic sections have benn chosen and studied (Estahban, Shams-Abad, Sarvestan and Akbar-Abad Sections). Field and laboratories study recognized 16 carbonate microfacies and 2 clastic-carbanate facies. Study of microfacies, relative sea level change and sequence stratigraphy evidences show these microfacies are deposited in carbonate ramp sedimentary environment in 5 facies belt zones: Open marine (A), Restricted (B), Shoal (C), Lagoon (D) and Tidal flat (E) during Oligomiocene. Petrography, microfacies analysis and sedimentary environment of Asmari formation shows this formation in study area consist of 3 depositional sequences. Lower sequence boundary of DS1 with Jahrum formation is erosional (disconformity) SB1. Lower and upper sequence boundary of DS2 is SB2. The upper sequence boundary of DS3 is SB1 and ended under the Razak clastic formation. In central Fars only lower part of Asmari is deposited and upper part of this formation have been eroded and disappeared.

\section{Keywords}

Petrography, Sedimentary Environment, Sequence Stratigraphy, Asmari Formation, Zagros, Iran

\section{Introduction}

Sediments related to Oligomiocene periods in central Fars include Asmari formation. The lower boundary of 
Asmari formations is bordering to Jahrum or Pabdeh formations from East to West of Shiraz (central Fars) and its upper boundary is adjacent to Razak or Gachsaran formations. Asmari formation is regarded as one of the most shallow oil prospects in the southwest of Iran, so it has long been considered by most geologists in Iran and throughout the world. The major lithology of Asmari formation includes limestone, dolomite, and dolomitic limestone. It should be noted that the sections under study is located in the trustified Zagros border zone where the intense functions of faults and high tectonic activity have led to displacement of layers and boundaries of formation [1] [2]. Accordingly, the purpose of the present study is petrography, microfacies analysis, depositional environments and sequence stratigraphy of Asmari formations in the central Fars in folded and trustified Zagros border.

\section{Methods \& Materials}

The method of this study includes laboratory and field studies. After reviewing aerial maps of the studied zone and several field visits, 4 stratigraphic sections were chosen and studied. From outcrops of Asmari formation in study area 500 thin sections were provided. In order to find Petrographic features of the studied sections, microscope with PPL and XPL light were applied. With regard to carbonate samples after determining type and percentage of allochem and orthochem elements, the samples were studied with the purpose of proceeding nomenclature and exact identification of sedimentary environment. For classification of carbonate microfacies uses of Dunham method (1962) [3] and in classifying facies and offering sedimentary model, Carrozi [4] and Flugel [5] methods were applied.

\section{Geologic and Stratigraphic Setting}

The study area is located central Fars in SW of Iran, which is Oligomiocene sediments in fold-thrust belt Zagros. The Zagros is the result of a multi-phased collision between the Arabian plate, the Neo-Tethys Ocean, and the central Iran micro plate [2]. As such, both 3 studied sections include two formations: Jahrum and Asmari. Figure 1 shows the geological setting and geographical location of the studied area.

The Iranian plateau extends over a number of continental fragments welded together along suture zones of oceanic character. The fragments are delineated by major boundary faults, which appear to be inherited from older geological periods. Each fragment differs in its sedimentary sequence, nature and age of magmatism and metamorphism, and its structural character and intensity of deformation. Figure 2 shows lithostratigraphical relationship between formations in Fars area, SW of Iran (Modified of James \& Wynd, 1975).

\section{Lithostratigraphy of the Studied Sections}

The geographic coordinates of the base of the selected sections, together with their lithostratigraphical characteristics are summarized in Table 1 . Figure 3 shows geographical situation of the studied sections in study area in SW of Iran. Geological map of studied area is shown in Figure 4.

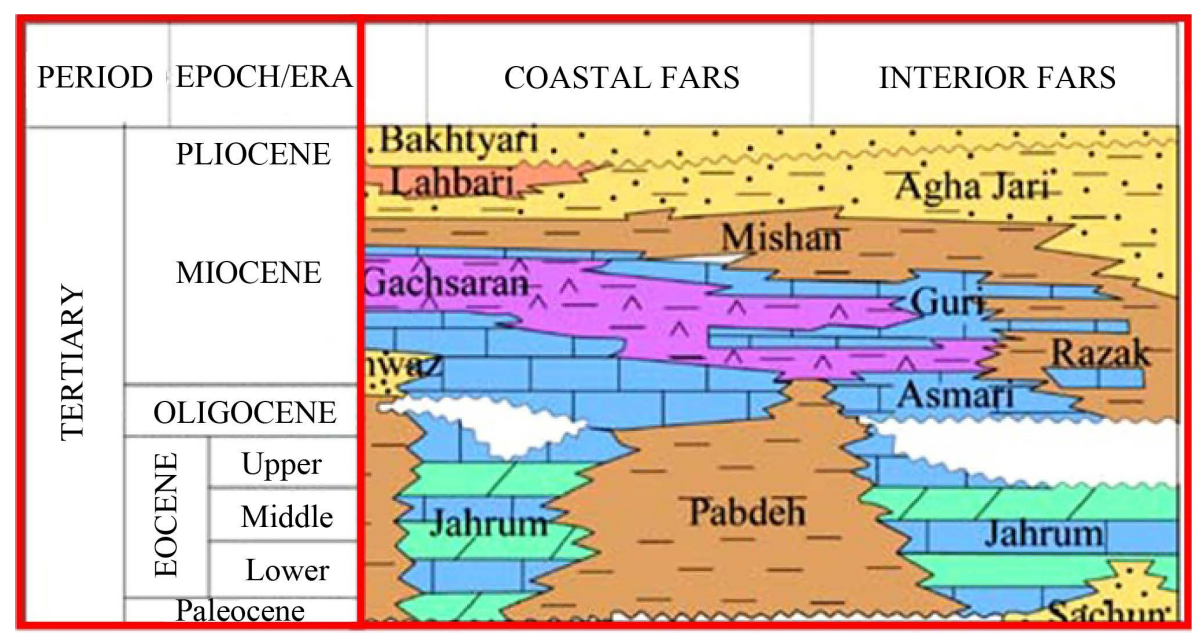

Figure 1. Geological setting and geographical location of the studied area. 


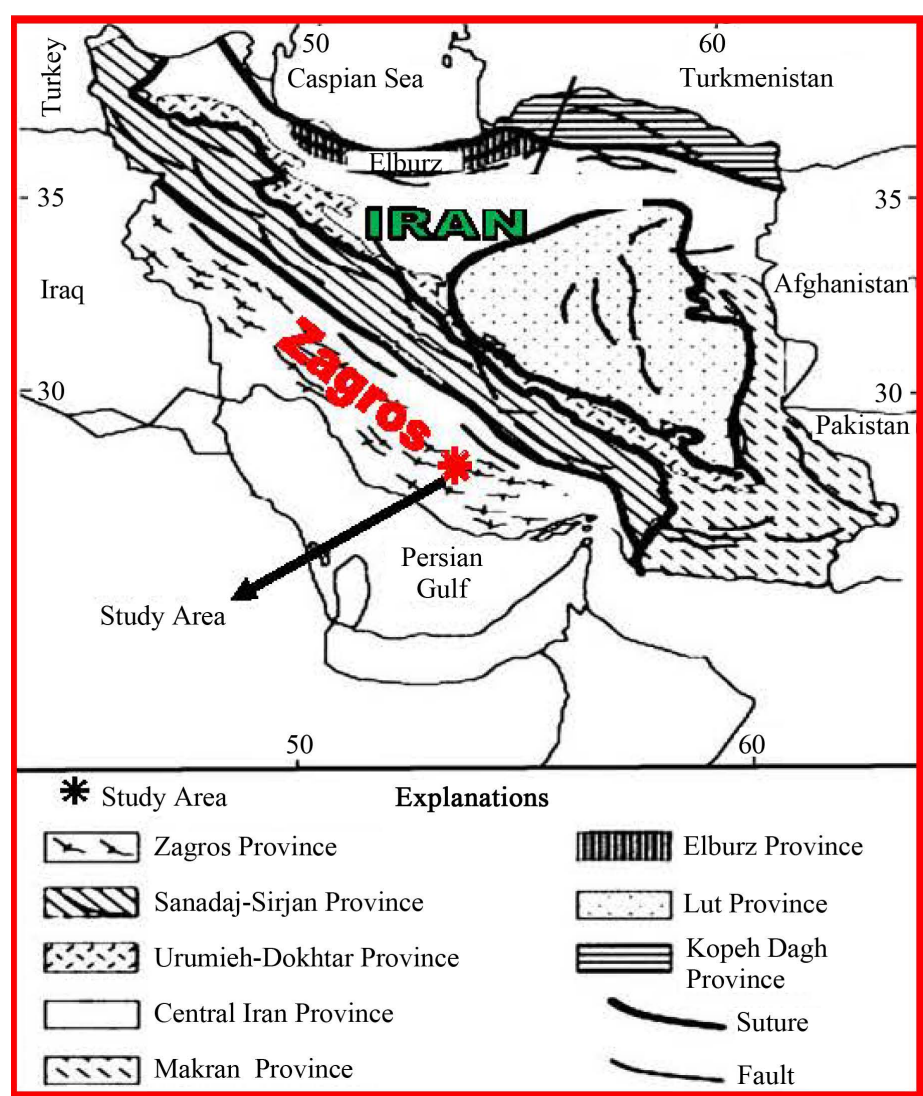

Figure 2. Lithostratigraphical relationship between formations in Fars area, SW of Iran (Modified of James \& Wynd, 1975).

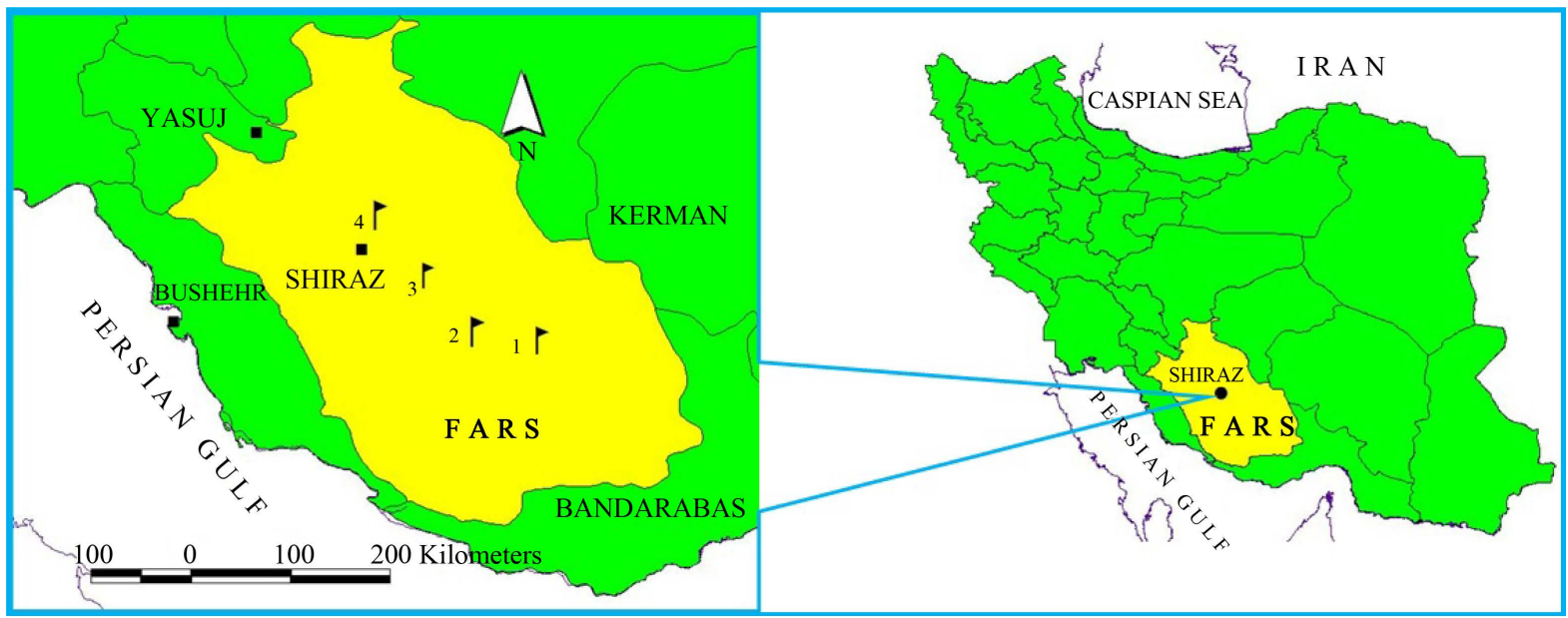

Figure 3. Geographical situation of the studied sections in study area: 1) Estahban Section; 2) Shams-Abad Section; 3) Sarvestan Section; and 4) Akbar-Abad Section.

\subsection{Estahban Section}

This section is located at 5 kilometers far away from Estahban-Shiraz road at the Western part of Estahban. The coordinates of the section base are $53^{\circ} 55^{\prime} \mathrm{E}$ and $29^{\circ} 7^{\prime} \mathrm{N}$. The Estahban Section stratigraphically covers Jahrum and Asmar formations and is generally 220 meters thick. The thickness of Asmari formations is 70 meters and has been formed by thin to moderate layers of partly dolomitic limestone with a soft morphology. In order to 


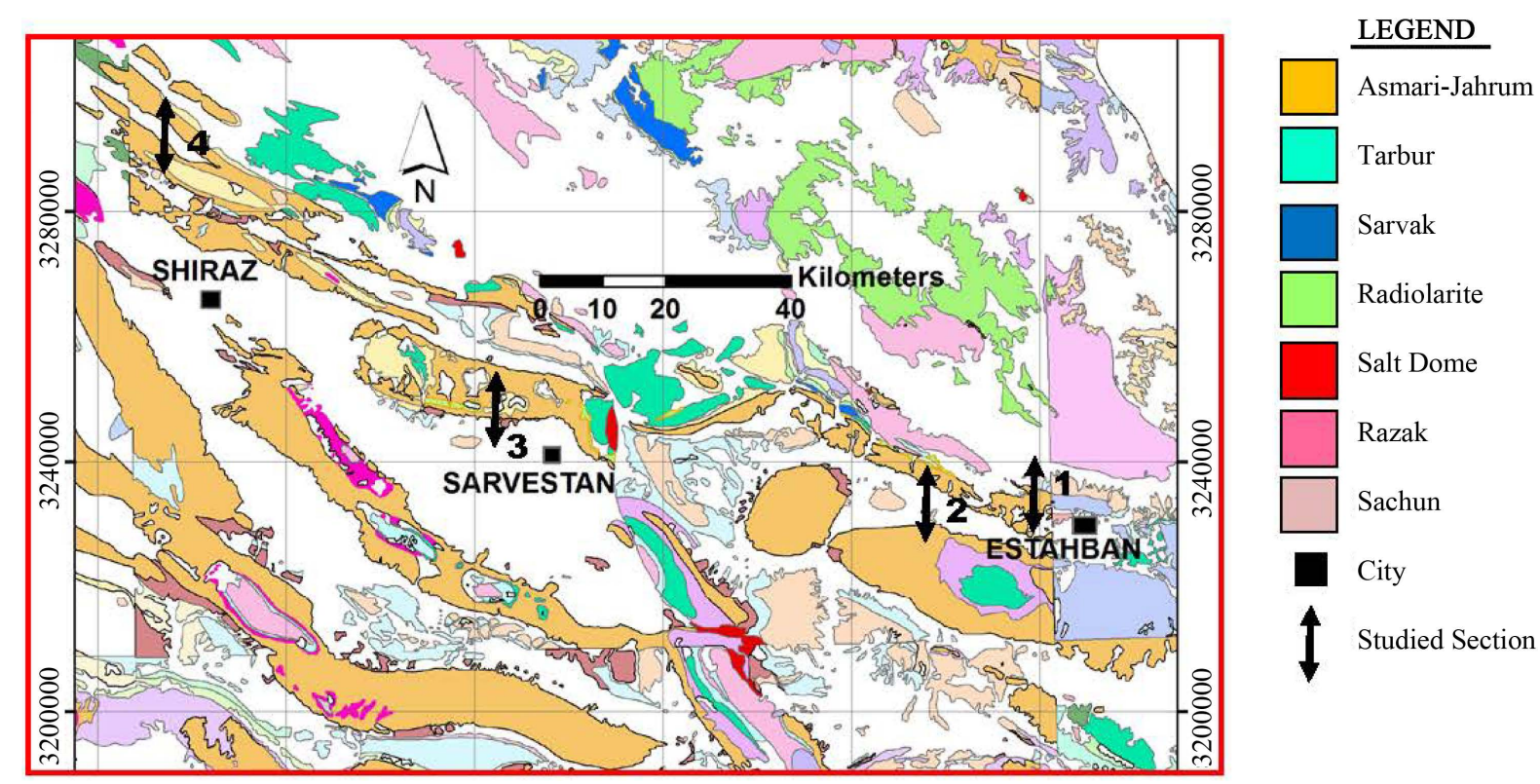

Figure 4. Geological map of studied area.

Table 1. The geographic coordinates and summarized lithostratigraphy of studied sections.

\begin{tabular}{|c|c|c|c|c|c|c|}
\hline Upper limit & $\begin{array}{l}\text { Asmari Fm. } \\
\text { Thickness }\end{array}$ & Lower limit & Coordinate & Lithology & Section & No \\
\hline Razak (SB1) & 70 & Jahrum (SB1) & $\begin{array}{l}53^{\circ} 55^{\prime} 36 " \mathrm{E} \\
29^{\circ} 7^{\prime} 59^{\prime \prime} \mathrm{N}\end{array}$ & $\begin{array}{l}\text { Limestone, Dolomitic Limestone, } \\
\text { Dolomite }\end{array}$ & Estahban Section & 1 \\
\hline Razak (SB1) & 80 & Jahrum (SB1) & $\begin{array}{l}53^{\circ} 55^{\prime} 36 " \mathrm{E} \\
29^{\circ} 7^{\prime} 59^{\prime \prime} \mathrm{N}\end{array}$ & $\begin{array}{l}\text { Limestone, Dolomitic limestone, } \\
\text { Sandy limestone }\end{array}$ & $\begin{array}{l}\text { Shams Abad } \\
\text { Section }\end{array}$ & 2 \\
\hline Razak (SB1) & 98 & Jahrum (SB1) & $\begin{array}{l}53^{\circ} 30^{\prime} 45 " \mathrm{E} \\
29^{\circ} 7^{\prime} 50^{\prime \prime} \mathrm{N}\end{array}$ & $\begin{array}{l}\text { Limestone, Dolomitic Limestone, } \\
\text { Dolomite }\end{array}$ & $\begin{array}{l}\text { Sarvestan } \\
\text { Section }\end{array}$ & 3 \\
\hline Razak (SB1) & 110 & Jahrum (SB1) & $\begin{array}{l}52^{\circ} 30^{\prime} 53^{\prime \prime} \mathrm{E} \\
29^{\circ} 41^{\prime} 39^{\prime \prime} \mathrm{N}\end{array}$ & $\begin{array}{l}\text { Limestone, Dolomitic Limestone, } \\
\text { Dolomite }\end{array}$ & $\begin{array}{l}\text { Akbar-Abad } \\
\text { Section }\end{array}$ & 4 \\
\hline
\end{tabular}

obtain better results, the samples were taken from the region in the northwest of Estahban near the Estahban ringway and also from Lower Kuhbar Section with coordinates of $54^{\circ} 3^{\prime} \mathrm{E}$ and $29^{\circ} 8^{\prime} \mathrm{N}$. Asmari formation in the auxiliary section has a thickness of about 75 meters and is composed of thin to moderate limestone and dolomitic limestone layers with a bright cream color.

\subsection{Shams-Abad Section}

This section is located at 15 kilometers far away from Estahban-Shiraz road at the Western part of Estahban. The coordinates of the section base are $53^{\circ} 55^{\prime} \mathrm{E}$ and $29^{\circ} 7^{\prime} \mathrm{N}$. The Shams-Abad Section stratigraphically covers Jahrum and Asmar formations and is generally 220 meters thick. The thickness of Asmari formations is 80 meters and has been formed by thin to moderate layers of weathered brown limestone and partly dolomitic limestone.

\subsection{Sarvestan Section}

This section is in Estahban Beltway where Islamic Azad university of Servestan is located. Its lower boundary with Jahrum formation is discontinuous and its upper boundary with Asmari formation is isoclines and discontinuous. Besides, the lower border of Jahrum formation at the anticline core with the Sachoon formation is sharp and the upper border of Jahrum formation with Asmari formation is erosive. The total thickness of the section under study is 250 meters. Asmary formation with a thickness of about 98 meters is composed of weathered red limestone and dolomitic limestone. The section base is located at $53^{\circ} 30^{\prime} \mathrm{E}$ and $29^{\circ} 7^{\prime} \mathrm{N}$. 


\subsection{Akbar-Abad Section}

This section is located at 10 kilometers far away from ringway of Shiraz Akbar-Abad. The coordinates of the section base are $52^{\circ} 30^{\prime} \mathrm{E}$ and $29^{\circ} 41^{\prime} \mathrm{N}$. The Akbar-Abad Section stratigraphically covers Jahrum and Asmar formations and is generally 310 meters thick. The thickness of Asmari formations is 110 meters and has been formed by thin to moderate layers of weathered brown limestone and partly dolomitic limestone about 35 meters top of this section conformed of Nummulitic brown limestone. Some field photos of studied sections are shown in Figure 5 and Figure 6.

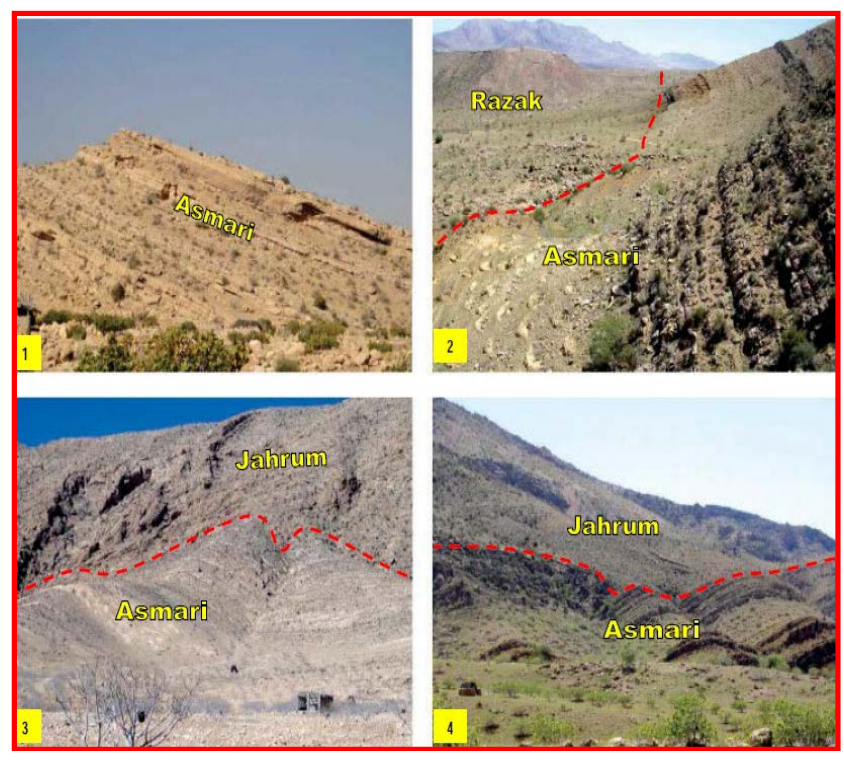

Figure 5. Some field photos of study area. 1) Thin to medium bedded limestone and Dolomitic limestone, Asmari formation, Estahban Section. 2) Thin to medium bedded limestone, sandy limestone in upper part of Asmari formation, Shams-Abad Section. 3) Thin to medium bedded limestone, Estahban Section. 4) Withered thin to medium limestone, Asmari formation, Shams-Abad Section.

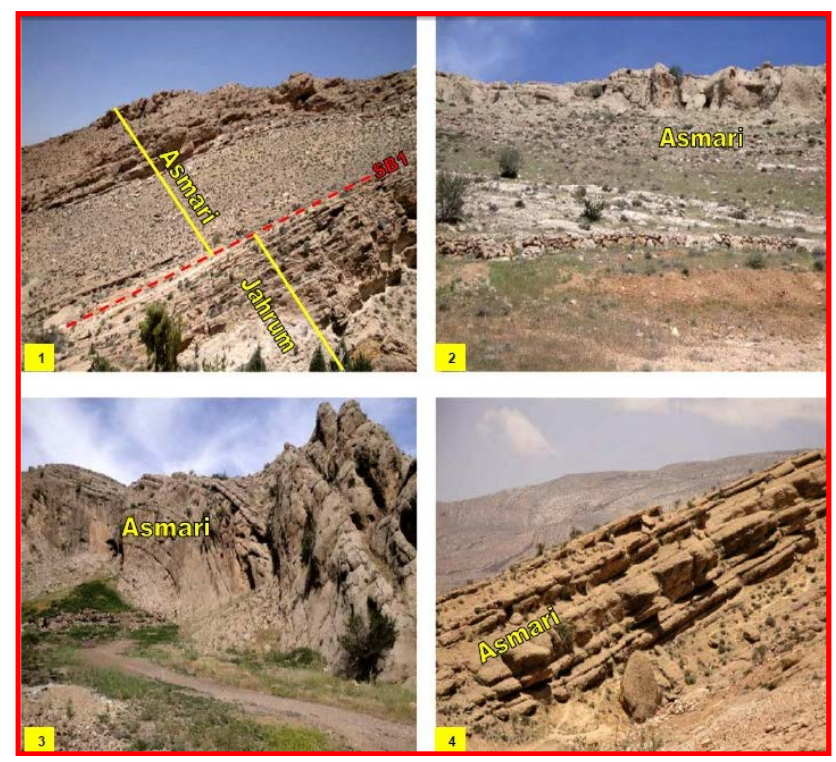

Figure 6. Some field photos of study area. 1) Thin to medium bedded limestone and Dolomitic limestone, Asmari formation, Sarvestan Section. 2) Medium to thick bedded limestone dolomitic limestone, Asmari formation, Akbar-Abad Section. 3) Massive bedded of Asmari formation, Akbar-Abad Section. 4) Withered medium to massive dolomite and dolomitic limestone, Asmari formation, Sarvestan Section. 


\section{Petrography and Microfacies Analysis of Asmari Formation of the Studied Sections}

A wide range of carbonate, clastic (Litofacies) facies has been identified in studied sections. Type of skeletal and non-skeletal grains, grain size and their frequency percentage, matrix and cement have been used to discriminate and identify carbonate facies from factors such as constituents of carbonate rocks including orthochem and allochem. Skeletal grains are mostly from Miliolidae, Algae, Nummulitidae, Soritidae and Lepidocyclynidae.

For studying microfacies, sedimentary environment and sequence stratigraphy of Asmari formations in study area, references including Vail et al. (1977) [6], Van Wagoner et al. (1988) [7], Nadjafi et al. (2004) [8], Emery and Myers (2005) [9], Schlager et al. (2005) [10], Zhang, X. et al. (2006) [11], Adabi et al. (2008) [12], Van Buchem et al. (2010) [13], Amirshahkarami et al. (2007 and 2010) [14] [15], Mirzaee Mahmoodabadi et al. (2013) [16] [17], and Mirzaee Mahmoodabadi (2014) [18] [19], have been used.

Non-skeletal grains include pellet and intraclast, the frequency of which in some samples reaches to $50 \%$. Nomenclature of the carbonate samples has been carried out by Dunham method [4]. In general, having precisely carried out the study and nomenclature of microfacies, the depositional model of each of the formations under study has been brought out according to the relative changes curve of the sea level based on their time. All in all, about 500 thin sections have been provided from the 4 studied sections and after precise study of the samples, the facies of Asmari formation were studied in detail, the abstract of which has been brought out in the following tables. Petrographic study and microscopic analysis of samples taken from the sections in Asmari formations reveals about 16 carbonate facies and 2 clastic facies (lithofacies) that have been deposited based on their vertical changes column in a carbonate platform made firm carbonate ramp related to Oligomiocene period (e.g., Tucker and Wright, 1990; Lasemi, 1995; and Flugel, 2010). These facies have been found in 5 belt zones of Open marine (A), Restricted (B), Shoal (C), Lagoon (D) and Tidal flat (E). Table 2 shows some microfacies along with a comparison of standard microfacies (SMF, RMF) and their alignment with facies belt zones (FZ) (Wilson, 1975 and Flugel, 2010) from the open marine environment towards the beach as follows:

\subsection{Carbonate Facies}

Major carbonate facies consist of limestone, dolostone and dolomitic limestone.

The main mineral constituents of these rocks are Aragonite $\left(\mathrm{CaCO}_{3}\right)$, Calcite $\left(\mathrm{CaCO}_{3}\right)$ and Dolomite $\mathrm{CaMg}\left(\mathrm{CO}_{3}\right)_{2}$. In study area carbonate facies under the microscope (microfacies) are deposited to 5 belt zones of Open marine (A), Restricted (B), Shoal (C), Lagoon (D) and Tidal flat (E).

\section{A: OPEN MARINE}

\section{A1. Mudstone}

This facies is composed entirely of calcareous clay with less than 10 percent plankton foraminifera. The existence of plankton bioclasts from deep marine and frequent micritic is indicative of deposition of this group of facies in the deep marine. This microfacies is equivalent to RMF No 1 and SMF No 3 Wilson 1975.

A2. Bentopelagic foraminifera Wackestone/Packstone

In this facies, shells of planctonic and bentonic foraminifera from moderate energy areas are located in a micritic setting. Skeletal elements include the family of Globorotalias, Globigrinoides, and bentonic foraminifera such as Nummulitidae and Lepidocyclinidae. This microfacies was deposited in an open marine. The occurrence of bentic and plagic foraminifera may point to depositional environment near the restricted facies belt zone. This microfacies is equivalent to RMF No 2 and SMF No 3 Wilson 1975.

A3. Bentonic foraminifera Packstone

This microfacies was divided into three submicrofacies such as Nummulites bioclast packstone, Operculina bioclast packstone and Lepidocyclina bioclast packstone. About $60 \%$ of this group of facies is made of shells of bentonic foraminifera. Some foraminifera such as Nummulites and Operculina in terms of paleoecological conditions live in outer ramp. Other bioclasts include echinoderms, bivalves and gastropods fragments. This microfacies is equivalent to RMF No 7, 8, 13 and SMF No 2 Flugel 2010.

\section{B: RESTRICTED}

B1: Pel bioclast Packstone

More than $50 \%$ of the total sample size comprises skeletal allochems such as Nummulitidae, Alveolindae, and Miliolidae families with about $15 \%$ of pellets and some intraclasts in this group of facies. Some similar facies, 
Table 2. Summarized of recognized microfacies of Asmari formation and comparison with RMF, SMF and facies belt zone.

\begin{tabular}{|c|c|c|c|c|c|c|c|}
\hline 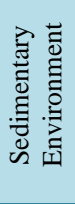 & 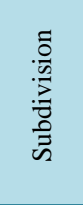 & 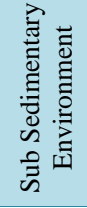 & No & $\begin{array}{c}\text { Standard Microfacies } \\
\text { (SMF, RMF, Facies Belt Zone, Erick Flugel, 2004) }\end{array}$ & RMF & SMF & FZ \\
\hline \multirow{16}{*}{ 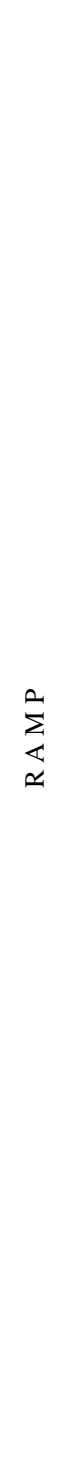 } & \multirow{3}{*}{ 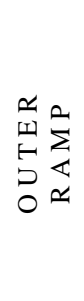 } & \multirow{3}{*}{ 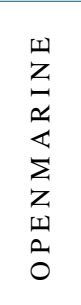 } & 1 & Mudstone & 1 & 3 & $\begin{array}{l}\text { FZ1 } \\
\text { FZ3 }\end{array}$ \\
\hline & & & 2 & Bentopelagic Foraminifera Wackestone/Packstone & 2 & 3 & $\begin{array}{l}\text { FZ1 } \\
\text { FZ3 }\end{array}$ \\
\hline & & & 3 & $\begin{array}{l}\text { Bentonic bioclast Packstone } \\
\text { 3-1. Nummulites bioclast Packstone } \\
\text { 3-2. Operculina bioclast Packstone } \\
\text { 3-3. Lepidocyclina bioclast Packstone }\end{array}$ & $7,8,13$ & 2 & $\begin{array}{l}\text { FZ2 } \\
\text { FZ3 } \\
\text { FZ4 }\end{array}$ \\
\hline & \multirow{3}{*}{ 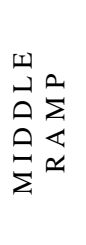 } & $\underset{⿴ 囗 十}{\ominus}$ & 4 & Pel bioclast Packstone & 7,9 & 11 & FZ6 \\
\hline & & $\stackrel{-}{\sim}$ & 5 & Intraclast bioclast Packstone & 7,9 & 17 & FZ7 \\
\hline & & $\begin{array}{l}\omega \\
\text { 되 } \\
\sim 1\end{array}$ & 6 & Archias bioclast Packstone & 13 & 18 & FZ7 \\
\hline & \multirow{10}{*}{ 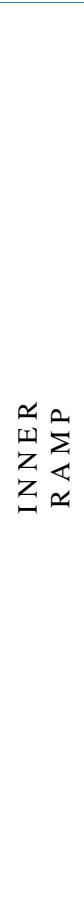 } & \multirow{3}{*}{ 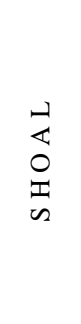 } & 7 & Austrotrilina bioclast Grainstone & 26 & 11,16 & $\begin{array}{l}\text { FZ6 } \\
\text { FZ7 } \\
\text { FZ8 }\end{array}$ \\
\hline & & & 8 & Miliolid bioclast Grainstone & 26 & 11,16 & $\begin{array}{l}\text { FZ6 } \\
\text { FZ7 } \\
\text { FZ8 }\end{array}$ \\
\hline & & & 9 & Intraclast bioclast Grainstone & 26 & 11,16 & $\begin{array}{l}\text { FZ6 } \\
\text { FZ7 } \\
\text { FZ8 }\end{array}$ \\
\hline & & & 10 & Miliolid bioclast Wackestone & 20,26 & 9,17 & $\begin{array}{l}\text { FZ7 } \\
\text { FZ8 }\end{array}$ \\
\hline & & $\begin{array}{l}z \\
0 \\
0\end{array}$ & 11 & Archias, Peneropelis bioclast Wackestone/Packstone & 20 & 11,16 & $\begin{array}{l}\text { FZ6 } \\
\text { FZ7 } \\
\text { FZ8 }\end{array}$ \\
\hline & & $\stackrel{\cup}{\longleftarrow}$ & 12 & Dolomitized bioclast Wackestone/ & 20 & 9,17 & $\begin{array}{l}\text { FZ7 } \\
\text { FZ8 }\end{array}$ \\
\hline & & & 13 & Algal Bioclast Packstone & 17 & 18 & $\begin{array}{l}\text { FZ } 7 \\
\text { FZ } 8\end{array}$ \\
\hline & & & 14 & Dolostone & \multicolumn{3}{|c|}{ SECOUNDARY } \\
\hline & & \multirow{2}{*}{ 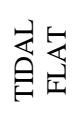 } & 15 & Dolomustone & 22 & 22, 23 & FZ9 \\
\hline & & & 16 & Stromatolite Boundstone & 28 & 22, 23 & FZ9 \\
\hline \multirow{2}{*}{\multicolumn{3}{|c|}{$\begin{array}{l}\text { Unconformity, SB1, Lower } \\
\text { boundary of Asmari formation }\end{array}$}} & 17 & Sandstone, Sandy Limestone & \multirow{2}{*}{\multicolumn{3}{|c|}{ EEPOSED AREA }} \\
\hline & & & 18 & Conglomerate, Microconglomerate & & & \\
\hline
\end{tabular}

the type and the percentage of skeletal allochems vary and sometimes the dolomitization process ranges from $10 \%$ to $20 \%$. The presence of large porcelaneous and hyaline form test also suggest deposition in the euphotic zone in restricted ramp environment. This microfacies is equivalent to RMF No 7, 9 and SMF No 11 Flugel 2010.

B2: Intraclast bioclast Packstone

The characteristics of this facies are similar to microfacies B1. However, its allochems, in addition to Miliolidae, are made of non-skeletal allochems such as about $20 \%$ intraclasts and $10 \%$ pellet. Besides, the percentages of allochems vary from $20 \%$ to $50 \%$ in similar samples. This microfacies is equivalent to RMF No 7,9 
and SMF No 17 Flugel 2010.

B3: Archias bioclast Packstone

This microfacies consists of about large bentonic foraminifera such as Archias sp. The main features of this microfacies are the maximum diversification of imperforate foraminifera in mud supported textures. Pellet, pelloid, intraclast and echinoid fragments are also present. This microfacies was deposited in a restricted ramp environment. This microfacies is equivalent to RMF No 13 and SMF No 18 Flugel 2010.

C: SHOAL

C1: Austrotrillina bioclast Grainstone

About $40 \%$ of skeletal allochems from Miliolidae family especially Austrotrillina species with a 0.2 to 1.5 $\mathrm{mm}$ diameter exist in this group of facies. These grains are floating in an environment of micritic matrix. Miliolidae spicies such as Austrotrillina howchini and Austrotrillina asmaicus live in inner ramp. This microfacies is equivalent to RMF No 26 and SMF No 11, 16 Flugel 2010.

C2: Miliolid bioclast Grainstone

In this group of facies, about $40 \%$ of skeletal allochems from Miliolidae and Alvoelindae families are in a sparite cement setting. The existence of sparite cement among allochems grains is indicative of displacement and deposition in the high energetic shoal environment. This microfacies is equivalent to RMF No 26 and SMF No 11, 16 Flugel 2010.

C3: Intraclast bioclast Grainstone

Common non-skeletal components in this microfacies are intraclas. Occurrence of intraclast and sparite calcite cement indicates the deposition in high energetic environment and resedimentation carbonate rocks in shoal sub sedimentary environment. This microfacies is equivalent to RMF No 26 and SMF No 11, 16 Flugel 2010.

\section{D: LAGOON}

D1: Miliolid bioclast Wackestone

About 35 percent of skeletal allochem grains from Miliolidae are present in this microfacies. The quantitative and qualitative level of microfossils varies in similar facies. A small percentage of pellets and sometimes intraclasts are floating in a micritic matrix. The existence of the Miliolidae family and allochems and micritemud supported texture is the evidence the deposition of this group of species in the relatively low energy environment in the inner ramp (lagoon). This microfacies is equivalent to RMF No 20, 26 and SMF No 9, 11 Flugel 2010.

D2: Archias, Peneropelis bioclast Wackestone/Packstone

In this microfacies, about 35\% of skeletal allochems grains are Archias and Peneropelis genus. The quality and quantity of microfossils are different in similar microfacies. In addition to these allochems, a small amount of pellets and intraclasts are floating in a micritic mud supported. The existence of these allochems and the micritic environment suggest the deposition of this group of facies in relatively quiet environment lagoons. The main features of this microfacies are maximum diversification of bentonic foraminifera. This microfacies is equivalent to RMF No 20 and SMF No 11, 16 Flugel 2010.

D3: Dolomitized bioclast Wackestone

In some similar samples, the diagenetic dolomitization process can be observed which varies from $15 \%$ to $75 \%$. The distructive fabrics in the dolomitization phenomena gradually destroy allochems and make it difficult to make a distinction between the type of allochems and the sedimentary environment. The neomorphism phenomenon can be observed clearly in the sample under study so that the sparitic cement is replaced for fossilized shells.

D4: Algal bioclast Packstone

In this facies about $35 \%$ of the skeletal allochem is red algae and Miliolidae family with average size of 0.5 $\mathrm{mm}$ in a micritic matrix. In the considered facies intraclasts are also seen with density of about $5 \%$. This microfacies was deposited in lagoonal area in ramp carbonated platform. This microfacies is equivalent to RMF No 17 and SMF No 18 Flugel 2010.

D5: Dolomite

The secondary dolomitic facies with a planar and non-planar fabric and amorphous and patterned crystals are found in Jahrum and Asmari formations. This group of facies includes ploidies that are dolomited in a micritic environment. Dolomite crystals are of a very small size and its mosaic texture is of xenotopic type. Given the size and the type of grain and the faces changes in the vertical sequence, these facies have been deposited in a tidal depositional environment towards the beginning of the lagoon. This group of facies can be found on the 
ground in the form of micro-crystalline dolomites with thin yellow and light grey layers in samples taken from Jahrum and Asmari formations.

E: TIDAL FLAT

E1: Dolomudstone

This microfacies includes ploidies that are dolomited in a micritic environment. Dolomite crystals are of a very small size and its mosaic texture is of xenotopic type. Given the size and the type of grain and the faces changes in the vertical sequence, these facies have been deposited in a tidal depositional environment towards the beginning of the lagoon. This group of facies can be found on the ground in the form of micro-crystalline dolomites with thin yellow and light grey layers.

E2: Stromatolite Boundstone

This facies is characterized as dark and light laminations and is formed when the sediment is trapped or attached to cyanobacteria. The form of evaporate and fabric bird's eye minerals are one of the prominent features of this group of facies. This microfacies was deposited in tidal flat and exposed area.

\subsection{Clastic Facies (Lithofacies)}

The main mineral constituents of these rocks are Quartz, Feldepar and rock fragments. In study area clastic facies consist of conglomerate and lime sandstone. These litology studied by field observation and microscopic data (PPL, XPL Polarized light).

\subsubsection{Conglomerate/Microconlomerate}

These facies are observed in the boundary between Asmari and Jahrum formations in the form of red microconglomerates containing reworked fossils immersed in hematite with high weathering. The existence of polycrystalline sedimentary quartzes in Jahrum formation and weathered lithoclasts stained with hematite in a calcite cement environment is a major characteristic of these clastic erosive facies. This group of facies can be put under Mial's (2006) classification of Gh: clast supported, horizontally stratified gravels. These facies are seen as alternative to microconglomerate facies in the form of fine to medium grained red weathered sandstone containing microfossils from Jahrum formation such as Nummulitidae family in the erosive boundary of Jahrum and Asmari formations. These facies belong to Mial's (2006) classification equivalent to Sm (massive sandstone).

\subsubsection{Lime Sandstone}

These facies are observed in the boundary between Asmari and Jahrum formations. This facies is litarenite sandstone with less silica rubbles and can be observed in a calcite cement environment with reworked microfossils. Recognized facies of Asmari formation shows in Table 2. Figures 7-10 shows some microscopic photos of microfacies.

\section{Sedimentary Environment of Asmari Formation in Study Area}

According to vertical distribution of the foraminifera, physical sedimentary structures, and facies geometric relations, 5 sub sedimentary environments have been identified for the Asmari formation in the study area in Oligomiocene. These 5 sub environments include Open marine (A), Restricted (B), Shoal (C), Lagoon (D) and Tidal flat (E) that these microfacies are deposited in carbonate ramp sedimentary. Given the described belts, carbonate ramp sedimentary model is suggested for Asmari formation. Figure 11 shows sedimentary environment model of Asmari formation in study area.

\section{Sequence Stratigraphy}

A comparison of micorofacies sequences of stratigraphic columns in Asmari formation in the region under study shows that Asmari formation has been deposited in a ramp-type carbonate platform. After the orogeny phase in the Pyrenean period in the region under study, Jahrum formation was eroded and its upper parts was eroded and disappeared from Eocene to Oligocene periods as in some areas under study including Sarvestan and only the lower Asmari is traceable., This part of the study deals with erosive facies of calcareous sandstone, sandy limestone, and microconglomerates on the ground especially in the section of Shams-Abad Section. After the progress of Oligocene marine, sediments of lower and middle Asmari formation in the area under study with the 


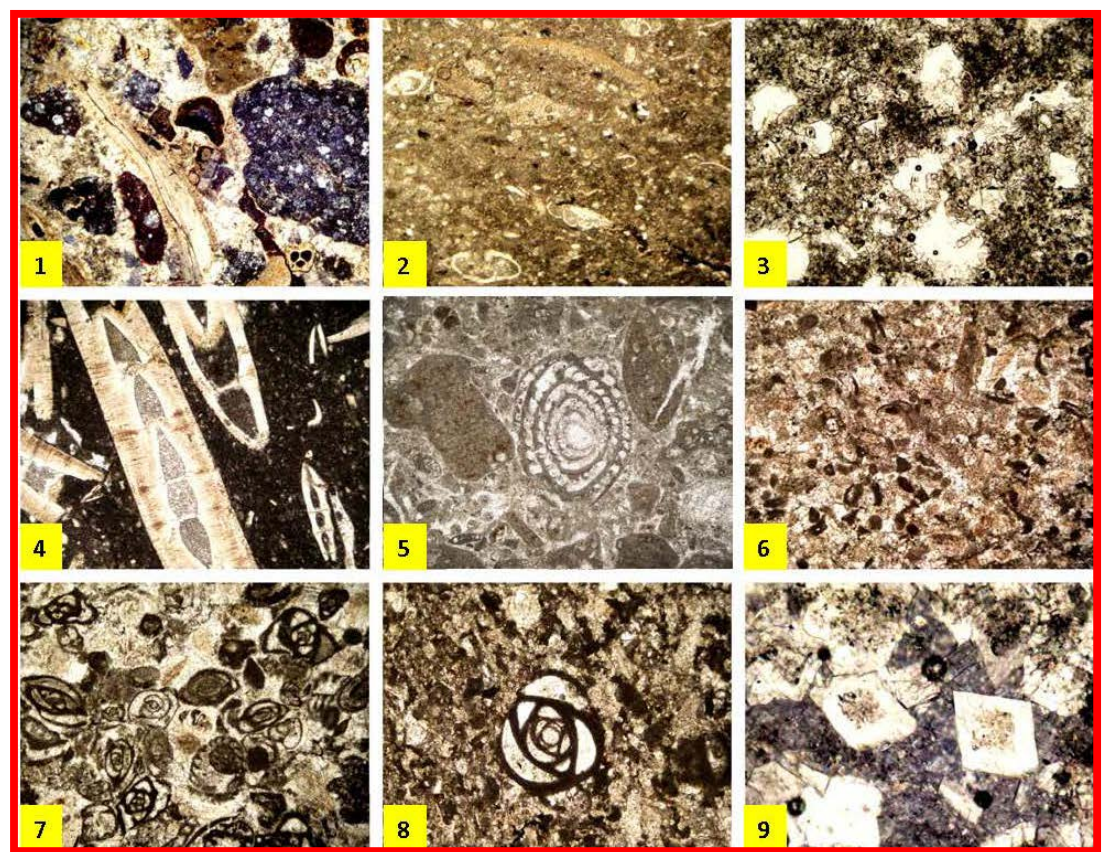

Figure 7. Some microfacies in study area: 1) Lime Sandstone, clastic facies, $\times 4$; 2) Bentopelagic bioclast Packstone, $\times 4$; 3) Dolomudstone with Fenestral fabric, $\times 4$; 4) Bentopelagic bioclast Packstone (Operculina $s p$ ), $\times 10$; 5) Intraclast bioclast Wackestone to Packstone, $\times 10$; 6) Pellet bioclast Packstone, $\times 4$; 7) Austrotrillina bioclast Grainstone (Austrotrillina sp, Peneropelis thomasi), $\times 4$; 8) Miliolid bioclast Packstone, $\times 10$; 9) Dolograinstone, dolomite rombohedral with opaque center and transparent rim, $\times 10$.

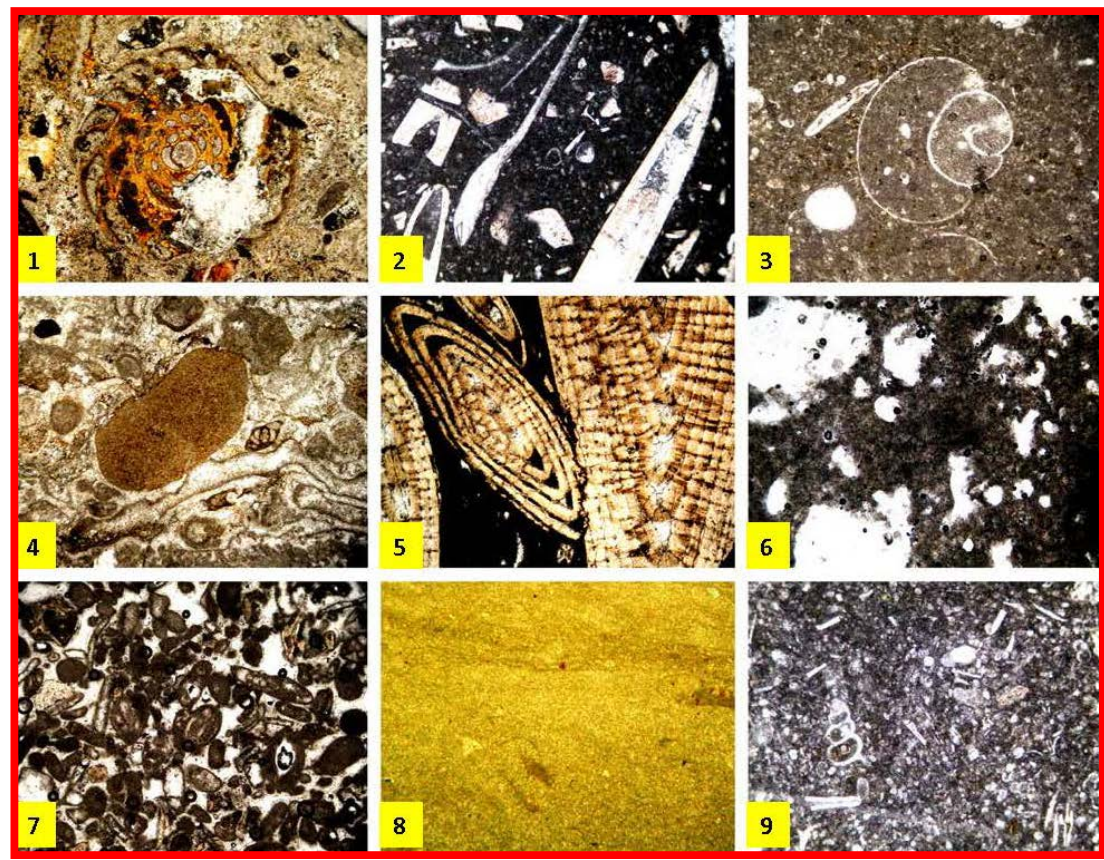

Figure 8. Some microfacies in study area: 1) Archias bioclast Packstone, $\times 4$; 2) Bentopelagic bioclast Packstone (Operculina sp), $\times 4$; 3) Intraclast bioclast Grainstone, $\times 10$; 4) Bentonic bioclast Packstone (Nummulites intermedius fichtelli), $\times 10$; 5) Nummulite bioclast Packstone, $\times 10$; 6) Dolomaudstone with fenestral fabric, $\times 4$; 7) Miliolid bioclast Grainstone, $\times 4$; 8) Mudstone, $\times 4$; 9) Bentopelagic bioclast Packstone, $\times 4$. 


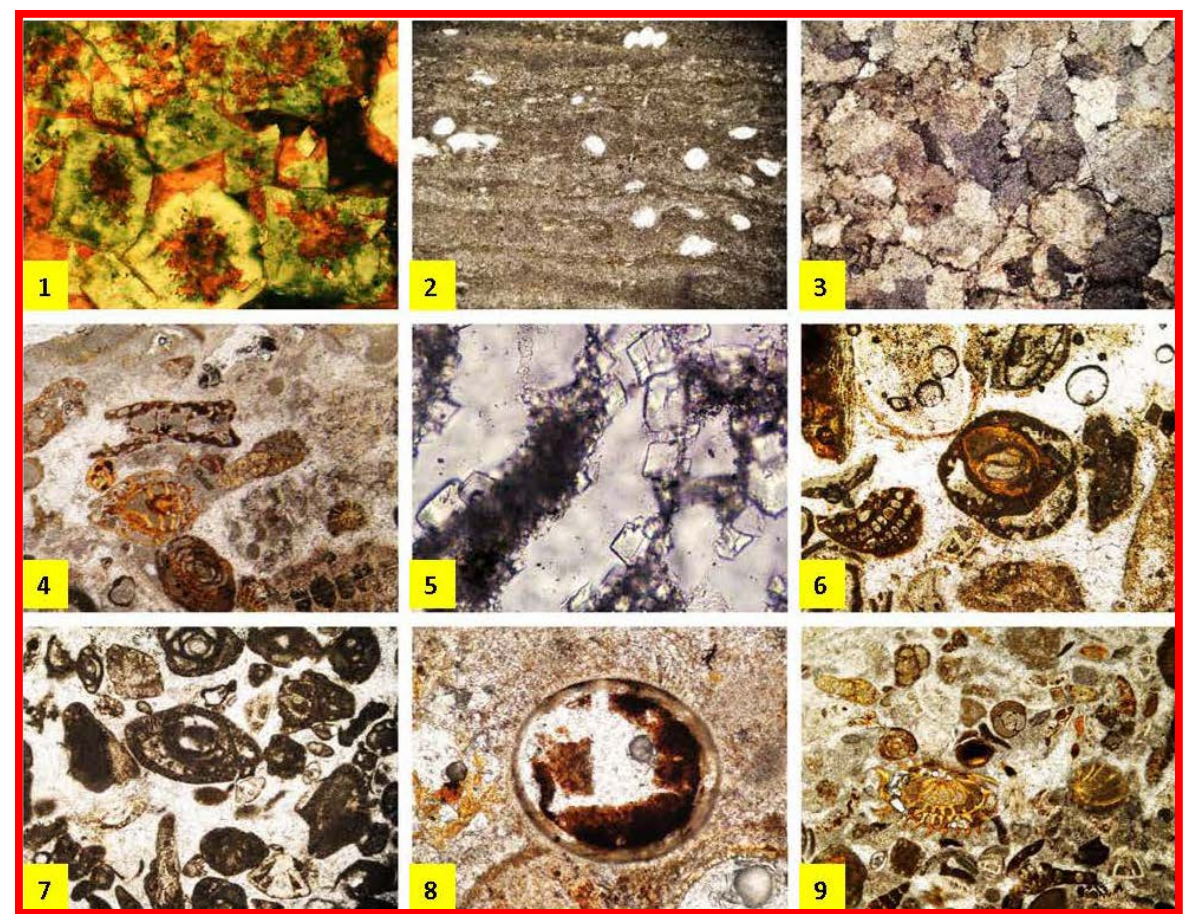

Figure 9. Some microfacies in study area: 1) Dolograinstone, $\times 10$; 2) Stromatolite Boundstone, $\times 2$; 3) Dolograinstone (Barouqe dolomite); 4) Archias bioclast Packstone, $\times 4$; 5) Dolograinstone in chemberlets of foraminifera with distructive fabric, $\times 10$; 6) and 7) Austrotrillina bioclast Grainstone (Austrotrillina asmarius), ×10; 8) Pel bioclast Packstone (Ditropa), $\times 10$; 9) Rotalia bioclast grainstone, $\times 4$.

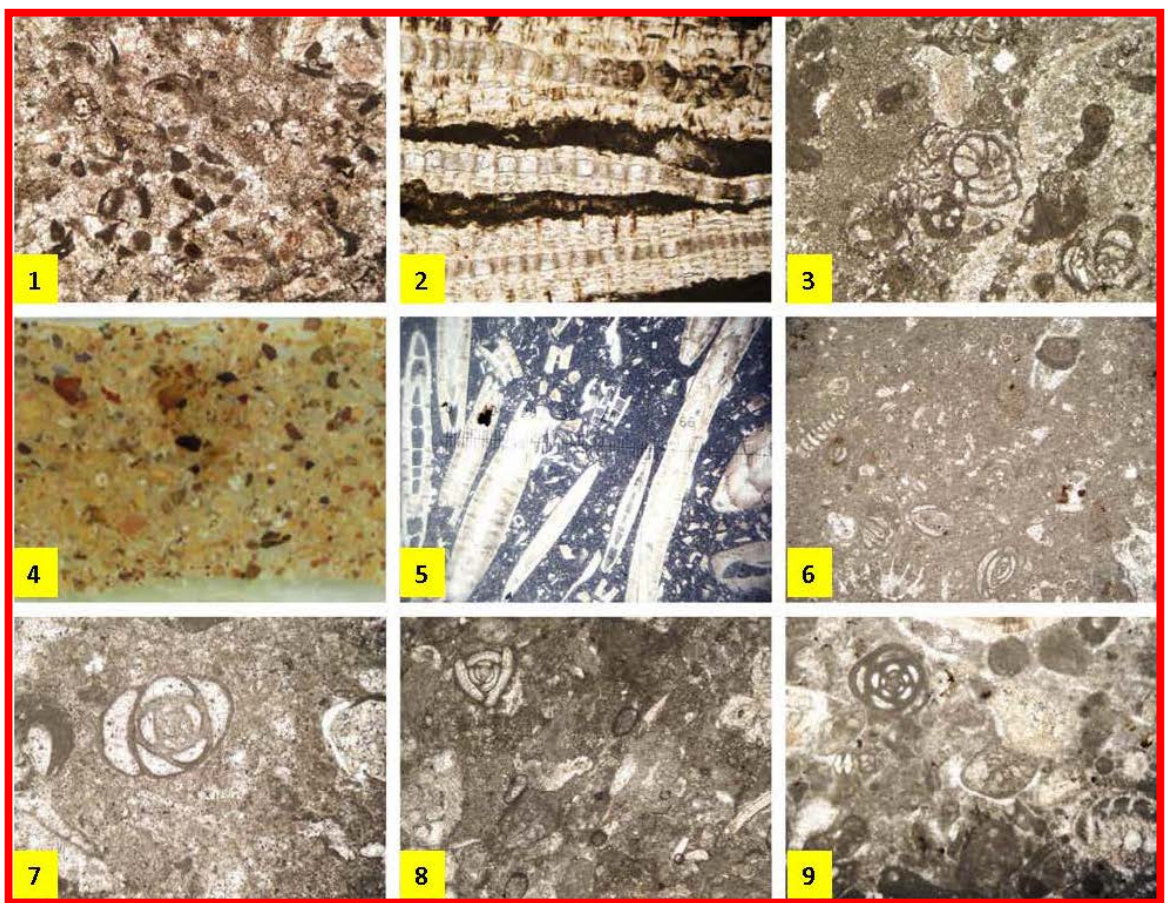

Figure 10. Some microfacies in study area: 1) Pel bioclast Packstone, $\times 4$; 2) Bentonic bioclast Packstone (Lepidocyclina bioclast Packstone), $\times 10$; 3), 6), 7), 8) and 9) Miliolid bioclast Wackestone to Packstone, $\times 4$; 4) Conglomerate, microconglomerate (SB1) $\times 10$; 5) Nummulites, Opercolina bioclast Packstone, $\times 10$. 


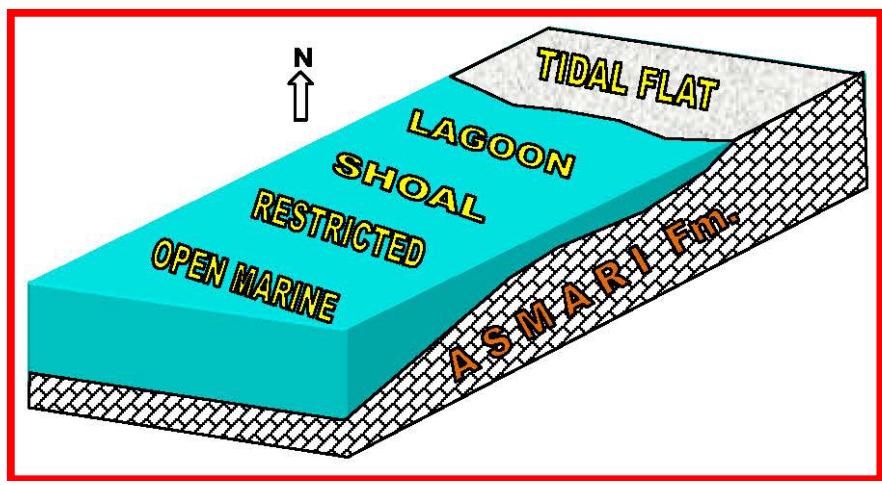

Figure 11. Sedimentary environment model of Asmari formation.

erosive boundary had been deposited on upper part of Jahrum formation. This section addresses sequential stratigraphy of the Asmari and Jahrum formations concerning vertical changes of microscopic facies to determine the boundaries of sequences and facies and relative changes in sea level in the area under study. Of course, the intense tectonic activities and faults functions have led to the displacement of some boundaries and layers of formations which makes the study of sequence stratigraphy more problematic..

\subsection{Sequence Stratigraphy of Asmari Formations in Estahban Section}

Asmari formation in this section has 81-meter thickness and includes 2 third-order sequences in Estahban Section. DS1: This depositional sequence with a thickness of 46 meters in lower part of Asmari formation was deposited in SB1 overlying on Jahrum formation. LST: This systems tract with about 1 meter conformed of microconglomerate and lime sandstone. This boundary is clearly marked on the ground for it contains iron compounds and paleosoil. TST system tract with a thickness of 10 meters is made of dolomitic limestone and thin bedded limestone. The recent advances in sea level (MFS) are shown by benthopelagic bioclast packstone microfacies. HST systems tract with a thickness of 35 meters is made of limestone and medium and thick layers of dolomitic limestone. DS2: Thickness of this depositional sequence is 35 meter. TST system tract is overlying on DS2 with SB2 sequence boundary. HST systems tract with 15 meter thickness consist of dolomitic limestone and limestone (Shoal, Lagoon and Tidal flat sub sedimentary environment microfacies) end with an erosional boundary under Razak Clastic Formation.

\subsection{Sequence Stratigraphy of Asmari Formations in Shams-Abad Section}

This section which is 80-meter thickness includes 2 third-order sequences. DS1: This depositional sequence with thickness 45 meters in lower part of Asmari formation was deposited in SB1 overlying on Jahrum formation. LST: This systems tract with about 2 meters is conformed of microconglomerate and lime sandstone. This boundary is clearly marked on the ground for it contains iron compounds and paleosoil. TST system tract with a thickness of 12 meters is made of dolomitic limestone and thin bedded limestone. The recent advances in sea level (MFS) are shown by benthopelagic bioclast packstone microfacies. HST systems tract with a thickness of 31 meters is made of limestone and medium and thick layers of dolomitic limestone. DS3: This depositional sequence with a thickness of 35 consists of TST and HST systems tract. TST systems tract with a thickness of 9 meters is made of limestone and thin bedded limestone. The recent advances in sea level (MFS) are shown by benthopelagic bioclast packstone microfacies. HST systems tract with a thickness of 26 meters is made of limestone and medium and thick layers of dolomitic limestone (mostly shoal and lagoonal microfacies, Table 2). This group of facies ends in SB1 erosive boundary under Razak formation (Figure 12, photo 2).

\subsection{Sequence Stratigraphy of Asmari Formations in Sarvestan Section}

Sarvestan Section in the region under study area is composed of 3 third-order sequences. DS1: This depositional sequence with a thickness of 45 meters was deposited in SB1 overlying on Jahrum formation. LST: This systems tract consist of microconglomerate and lime sandstone. TST system tract with a thickness of 22 meters is 

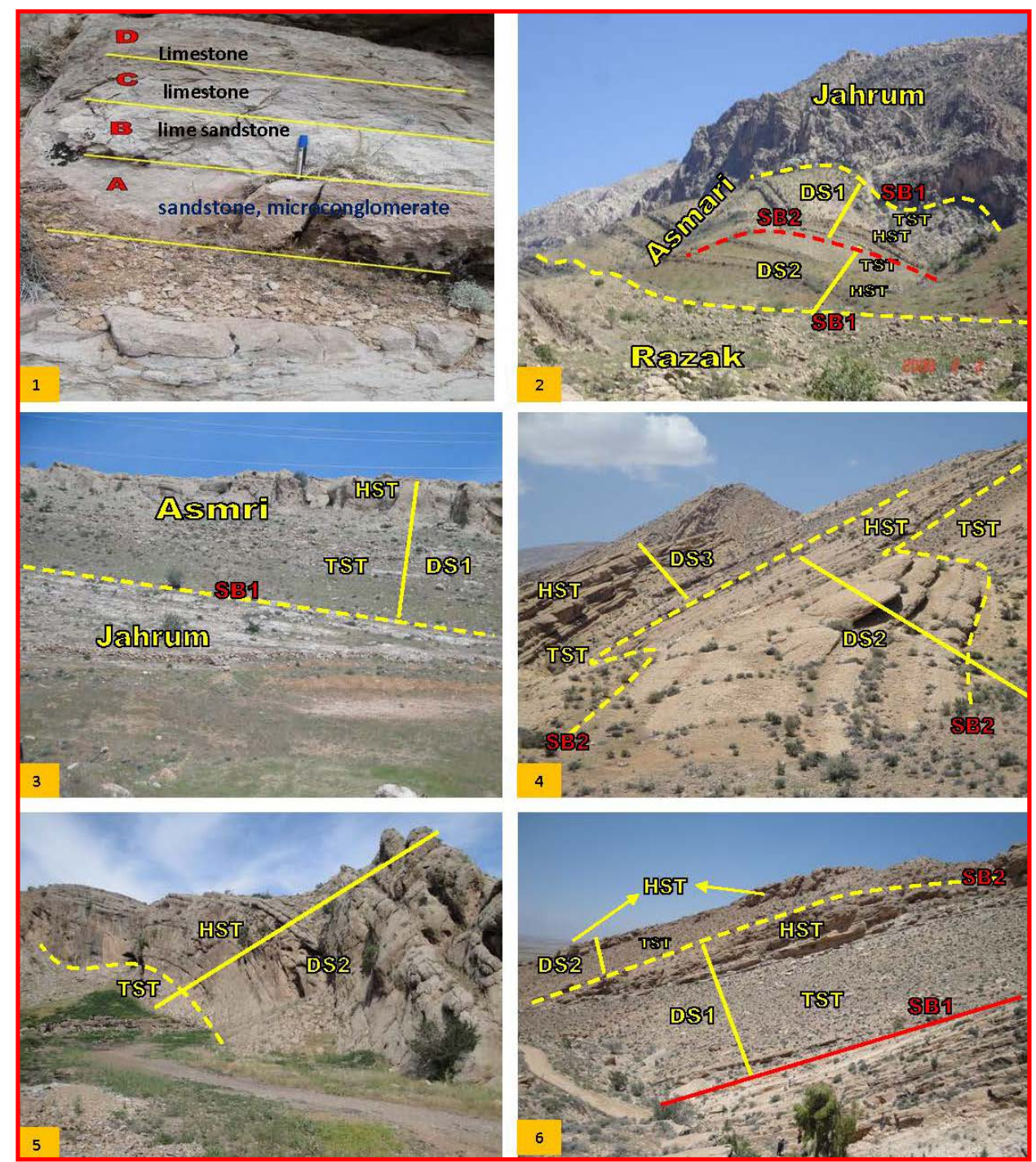

Figure 12. Some field photos of sequence stratigraphy of Asmari formation in study area. 1) Sequence Boundary type 1 (SB1) between Jahrum and Asmari formation, this contact conformed of sandy limestone, lime sandstone, microconglomerate and iron oxide debris. 2) DS1 and DS2 in Shams-Abad Section. 3) DS1 in Akbar-Abad Section. 4) DS2 and DS3 in Sarvestan Section. 5) DS2 in Akbar-Abad Section. 6) DS1 and DS2 in Sarvestan Section.

thin bedded limestone. MFS are shown by benthopelagic bioclast packstone microfacies. HST systems tract with a thickness of 21 meters is made of limestone and medium and thick layers of weathered dolomitic limestone. DS2: This sequence is 35 meters thick in which TST facies are approximately 15 meters thick and are made mostly of benthopelagic bioclast microfacies. Thickness of HST facies of this sequence is approximately 20 meters. These facies are made mainly of alternative lagoonal and shoal facies which are characterized by increasing the thickness of layers. The lower boundary of the first sedimentary sequence is a gradual SB2 boundary with DS2 is SB2. DS3: This depositional sequence with a thickness of 18 meters includes TST and HST facies. Its lower boundary with the second depositional sequence is of SB2 type and its upper boundary with Razak formation is a SB1 erosional boundary. The upper parts of the third sedimentary sequence have been disappeared and eroded (Figure 12, photo 4 and photo 6).

\subsection{Sequence Stratigraphy of Asmari Formations in Akbar-Abad Section}

Akbar-Abad Section in the study area with 110 meters is composed of 2 third-order sequences. DS1: Thickness 
sequence is 70 meters and include LST, TST and HST systems tract. LST: This systems tract with approximately 2 meters conformed of microconglomerate and lime sandstone (Figure 12, photo 1). TST system tract with a thickness of 20 meters is made of dolomitic limestone and thin bedded limestone. The recent advances in sea level (MFS) are shown by benthopelagic bioclast packstone microfacies. HST systems tract with a thickness of 48 meters is made of limestone and medium and thick layers of dolomitic limestone. DS2: This sequence is 70 meters thick in which TST facies are approximately 15 meters thick and are made mostly of benthonic bioclast microfacies. Thickness of HST facies of this sequence is approximately 25 meters. These facies are made mainly of alternative lagoonal and shoal facies which are characterized by increasing the thickness of layers. This systems tract ends by SB1 below clastic Razak formation. Table 3 shows summarized of sequence stratigraphy of Asmari formation in study area (Figure 12, photo 3 and photo 5).

\section{Conclusions}

Based on field and laboratory observation in Asmari formation in study area, 16 carbonate facies and 2 clastic-carbonate facies have been recognized.

Carbonated facies include Mudstone, Bentopelagic foraminifera Wackestone/Packstone, Bentonic foraminifera Packstone, Pel bioclast Packstone, Intraclast bioclast Packstone, Archias bioclast Packstone, Austrotrillina bioclast Grainstone, Miliolid bioclast Grainstone, Intraclast bioclast Grainstone, Miliolid bioclast Wackestone, Archias, Peneropelis bioclast Wackestone/Packstone, Dolomitized bioclast Wackestone, Algal bioclast Packstone, Dolomite, Dolomudstone and Stromatolite Boundstone.

Clastic facies (Lithofacies) include Conglomerate/Microconlomerate and Lime sandstone.

Given their vertical changes columns, these facies have been deposited on a carbonate ramp platform related Oligomiocene periods. This facies can be found in five facies belt zone of Open marine (A), Restricted (B), Shoal (C), Lagoon (D), and Tidal flat (E).

Field and laboratory studies in study area recognized three depositional sequences.

Lower sequence boundary of DS1 in 4 studied sections is type one (SB1) with Jahrum formation.

Lower sequence boundary of DS2 in Estahban, Shams-Abad and Akbar-Abad Sections are type 2 (SB2) and upper sequence boundary with Razak formation is SB1.

Table 3. Summarized of sequence stratigraphy of Asmari formation in study area.

\begin{tabular}{|c|c|c|c|c|c|c|c|c|}
\hline S.S & DS & $\mathrm{Tm}$ & L.S.B & LST m & TST & MFS & HST & U.S.B \\
\hline \multirow[b]{2}{*}{ Estahban } & DS1 & 45 & $\begin{array}{l}\text { SB1 with } \\
\text { Jahrum }\end{array}$ & 1, Paleosoil & 10 & $\begin{array}{l}\text { Benthopelagic bioclast } \\
\text { Packstone foraminifera }\end{array}$ & 35 & SB2 \\
\hline & DS2 & 25 & SB2 & - & 10 & $\begin{array}{l}\text { Benthopelagic bioclast } \\
\text { Packstone foraminifera }\end{array}$ & 15 & $\begin{array}{l}\text { SB1 with } \\
\text { Razak } \\
\text { formation }\end{array}$ \\
\hline \multirow[b]{2}{*}{ Shams-Abad } & DS1 & 45 & $\begin{array}{l}\text { SB1 with } \\
\text { Jahrum }\end{array}$ & $\begin{array}{l}2 \mathrm{~m} \text {, microconglomerate, } \\
\text { lime sandstone }\end{array}$ & 12 & $\begin{array}{l}\text { Benthopelagic bioclast } \\
\text { Packstone foraminifera }\end{array}$ & 31 & SB2 \\
\hline & DS2 & 35 & SB2 & - & 9 & $\begin{array}{l}\text { Pelagic bioclast } \\
\text { Packstone }\end{array}$ & 26 & $\begin{array}{l}\text { SB1 with } \\
\text { Razak } \\
\text { formation }\end{array}$ \\
\hline \multirow{3}{*}{ Sarvestan } & DS1 & 45 & $\begin{array}{l}\text { SB1 with } \\
\text { Jahrum }\end{array}$ & $\begin{array}{l}2 \mathrm{~m} \text {, microconglomerate, } \\
\text { lime sandstone }\end{array}$ & 22 & $?$ & 21 & SB2 \\
\hline & DS2 & 35 & SB2 & - & 15 & $?$ & 20 & SB2 \\
\hline & DS3 & 18 & SB2 & & 8 & $?$ & 10 & $\begin{array}{l}\text { SB1 with } \\
\text { Razak } \\
\text { formation }\end{array}$ \\
\hline \multirow{2}{*}{ Akbar-Abad } & DS1 & 70 & $\begin{array}{l}\text { SB1 with } \\
\text { Jahrum }\end{array}$ & $\begin{array}{l}2 \mathrm{~m} \text {, microconglomerate, } \\
\text { lime sandstone }\end{array}$ & 20 & $\begin{array}{l}\text { Benthopelagic bioclast } \\
\text { Packstone foraminifera }\end{array}$ & 48 & SB2 \\
\hline & DS2 & 40 & SB2 & - & 15 & $\begin{array}{l}\text { Benthopelagic bioclast } \\
\text { Packstone foraminifera }\end{array}$ & 25 & SB2 \\
\hline
\end{tabular}

S.S = Studied Section; DS = Depositional Sequence; T m = Thickness (meter); L.S.B = Lower Sequence Boundary; LST $\mathrm{m}=$ Lowstand Systems Tract (meter); TST = Transgressive Systems Tract; MFS = Maximum Flooding Surface; HST = Highstand Systems Tract; U.S.B = Upper Sequence Boundary. 
Lower sequence boundary of DS3 in Sarvestan Section is type 2 (SB2) and upper sequence boundary with Razak formation is SB1.

The upper parts of the last depositional sequence have been eroded and disappeared.

\section{Acknowledgements}

This study is supported with research project of Islamic Azad University Estahban Branch, Estahban, Iran and the author appreciates for providing the financial support.

\section{References}

[1] Motiei, H. (1993) Stratigraphy of Zagros. Treatise on the Geology of Iran, Geological Survey of Iran, No 1, 536 p.

[2] Alavi, M. (1994) Tectonic of Zagros Orogenic Belt of Iran: New Data and Interpretations. Tectonophysics, 229, 211238. http://dx.doi.org/10.1016/0040-1951(94)90030-2

[3] Dunham, R.J. (1962) Classification of Carbonate Rocks According to their Depositional Texture. AAPG, M 1, $108-121$.

[4] Carozzi, A.V. (1989) Carbonate Rocks Depositional Model. Prentice Hall, Englewood Cliffs, 604 p.

[5] Flügel, E. (2004) Microfacies of Carbonate Rocks, Analysis, Interpretation and Application. Springer, Berlin, 976 p.

[6] Vail, P.R.F., Audemard, S.A.P.R., Bowman, D., Eisner, N. and Perezcruz, C. (1988) The Stratigraphic Signatures of Tectonics, Eustasy and Sedimentology-An Overview. In: Einsele, G., Ricken, W. and Seilasher, A., Eds., Cycles and Events in Stratigraphy, Springer-Verlag, Berlin, 617-659.

[7] Van Wagoner, J.C., Posamentier, H.W., Mitchem, R.M., Vail, P.R., Sarg, J.F., Loutit, T.S. and Hardenbol, J. (1988) An Overview of the Fundamentals of Sequence Stratigraphy and Key Definitions. In: Wilgus, C. K., Hasting, B.S., Kendall, C.G.St.C., Posmentier, H., Ross, C.A. and Van Wagoner, J.C., Eds., Sea Level Changes: An Integrated Approach, SEPM Special Publication 42, Darlington, 39-45.

[8] Nadjaf, M., Mahboubi, A., Moussavi-Harami, R. and Mirzaee Mahmoodabadi, R. (2004) Depositional History and Sequence Stratigraphy of Outcropping Tertiary Carbonates in the Jahrum and Asmari Formations, Shiraz Area (SW Iran). Journal of Petroleum Geology, 27, 179-190. http://dx.doi.org/10.1111/j.1747-5457.2004.tb00052.x

[9] Emery, D. and Myers, K. (2005) Sequence Stratigraphy. Blackwell Science, Oxford, 297 p.

[10] Schalger, W., Reijmer, J.J.G. and Droxler, A. (1994) Highstand Shedding of Carbonate Platforms. Journal of Sedimentary Research, 64, 270-281.

[11] Zhang, X.Q., Lin, J.N., Li, G. and Ling, Q.X. (2006) Non-Marine Cretaceous-Paleogene Boundary Section at Datang of Nanxiong, Northern Guangdong. Journal of Stratigraphy, 30, 327-340. (In Chinese)

[12] Adabi, M.H., Zohdi, A., Ghabeishavi, A. and Amiri-Bakhtiyar, H. (2008) Applications of Nummulitids and Other Larger Benthic Foraminifera in Depositional Environment and Sequence Stratigraphy: An Example from the Eocene Deposits in Zagros Basin, SW Iran. Facies, 54, 499-512. http://dx.doi.org/10.1007/s10347-008-0151-7

[13] Van Buchem, F.S.P., Pittet, B., Vtner, H., Geo Tsch, J., Man Souri, A.I., Billing, I.M., Droste, H.H.F., Oterdoom, W.H. and Van Steenwinkel, M. (2002) High-Resolution Sequence Stratigraphie Architeeture of Barremian/Aptiam Earbonate Systems in Northern Oman and the United Arab Emirates (Kharaib and Shuaib a Formation). GeoArabia, 7, 461-500.

[14] Amirshahkarami, M., Vaziri-Moghaddam, H. and Taheri, A. (2007) Sedimentary Facies and Sequence Stratigraphy of Asmari Formation at Chaman-Bolbol, Zagros Basin, Iran. Journal of Asian Earth Sciences, 29, 947-959.

[15] Amirshahkarami, M, Ghabishavi, A. and Rahmani, A. (2010) Biostratigraphy and Paleoenvironment of the Larger Benthic Foraminifera in Wells Sections of the Asmari Formation from the Rag-e-Safid Oil Field, Zagros Basin, Southwest Iran. Stratigraphy and Sedimentology Researches, 26, 63-84.

[16] Mirzaee Mahmoodabadi, R. (2013) Depositional Environments and Sequence Stratigraphy of Paleocene-Eocene Sediments in Shiraz Area, Fars, Zagros, Iran. IAS (International Association of Sedimentology), Manchester.

[17] Mirzaee Mahmoodabadi, R. (2013) Paleoecology and Quantitative Study of Bentonic and Pelanktonic Foraminifera of Pabdeh Formation Based on Sequence Stratigraphy Evidences in Shiraz, Fars, Zagros, Iran. IAS (International Association of Sedimentology), Manchester.

[18] Mirzaee Mahmoodabadi, R. (2014) Sedimentary Environments and Correlative Sequence Stratigraphy of Upper Cretaceous - Paleogene Succession in Shiraz Area, Fars, SW IRAN. Open Journal of Geology, 4, 1-17. http://dx.doi.org/10.4236/ojg.2014.41001

[19] Mirzaee Mahmoodabadi, R. (2014) Sequence Microbiostratigraphy of Jahrum and Asmari Formations in Shiraz Area, Zagros, Fars, SW, Iran. Open Journal of Geology, 4, 93-107. http://dx.doi.org/10.4236/ojg.2014.44009 
Scientific Research Publishing (SCIRP) is one of the largest Open Access journal publishers. It is currently publishing more than 200 open access, online, peer-reviewed journals covering a wide range of academic disciplines. SCIRP serves the worldwide academic communities and contributes to the progress and application of science with its publication.

Other selected journals from SCIRP are listed as below. Submit your manuscript to us via either submit@scirp.org or Online Submission Portal.
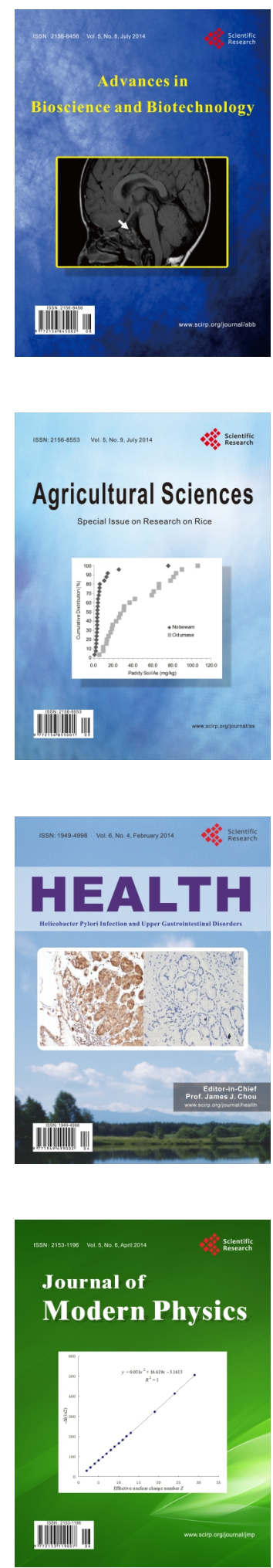
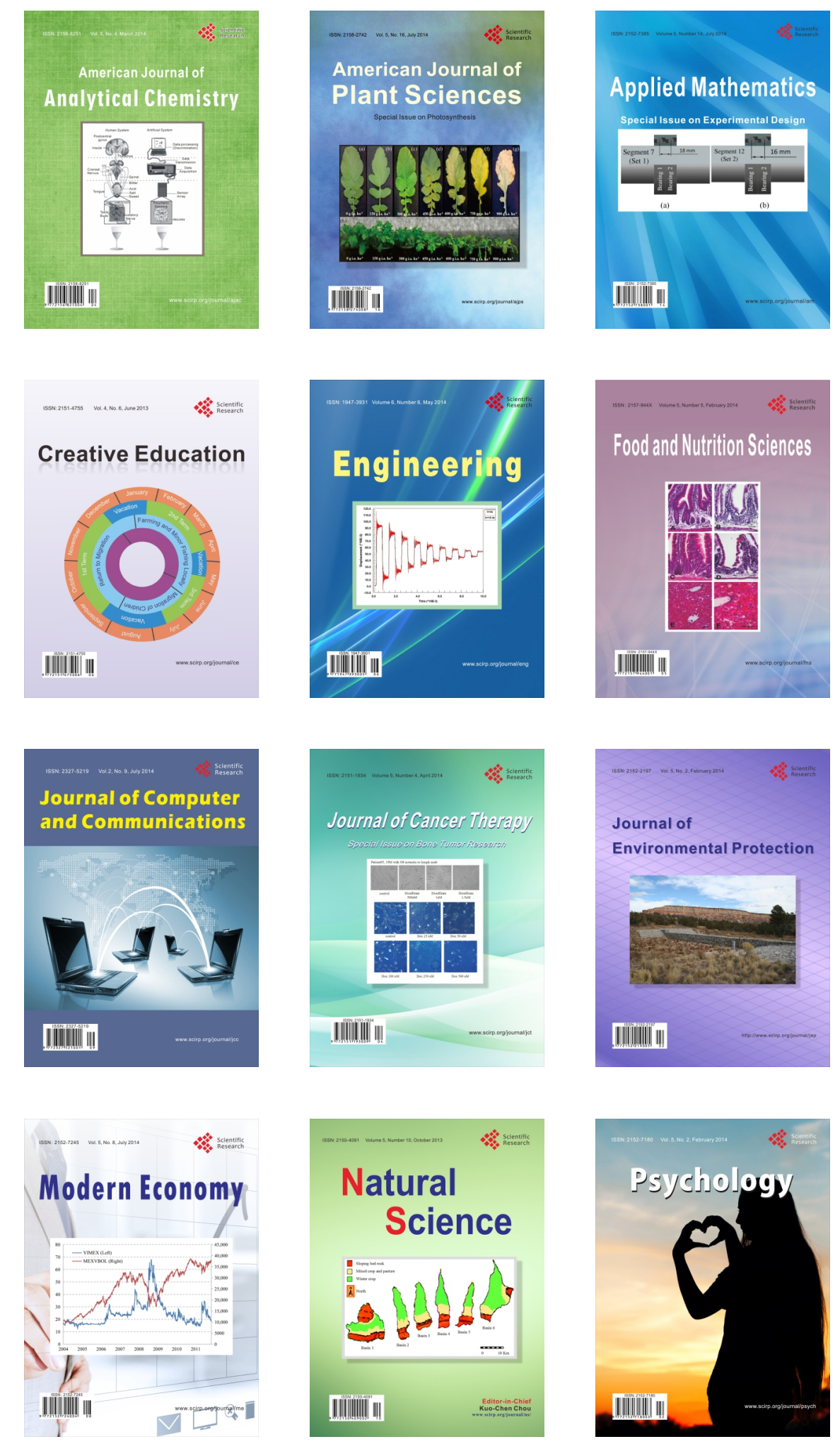